\title{
The Inaudible Music of the Renaissance: From Marsilio Ficino to Robert Fludd
}

\author{
ROSEEN H. GILES \\ University of Toronto
}

\begin{abstract}
This article revaluates the significance of musical treatises written by the Ficinian physician Robert Fludd (1574-1637). By reconsidering the implications of Fludd's interpretation of Marsilio Ficino's musical philosophy, I propose that his "reconstruction" of the Renaissance outlook in the seventeenth century is not merely a backward-looking oddity, but is rather indicative of a long-standing and pervasive history of inaudible music (i.e., the "silent" harmony of the universe and of the human body). Music played a central role in Fludd's polemics with the scientists Johannes Kepler (1571-1630) and Marin Mersenne (1588-1648), regarding not the composition of art music but rather the understanding of the composition of the universe itself. The societal tensions evident in Fludd's musical books reveal that it is not only musical practice but also broad scientific, medical, and philosophical conceptions of sound that comprise musical understanding in the early seventeenth century.
\end{abstract}

Cet article propose de réévaluer la signification des traités de musique du médecin ficinien Robert Fludd (1574-1637). En reconsidérant ce qu'implique l'interprétation par Fludd de la philosophie musicale de Marsile Ficin, il avance que cette "reconstruction " d'une perspective issue de la Renaissance au XVII siècle ne correspond pas seulement à un excentrique retour en arrière; elle réfère plutôt à la longue et omniprésente histoire de cette musique inaudible qu'est l'harmonie des sphères (comprise comme harmonie silencieuse de l'univers et du corps humain). La musique a en effet joué un rôle important dans les échanges polémiques entre Fludd, Johannes Kepler (1571-1630) et Marin Mersenne (1588-1648), qui ne portent pas tant sur la composition musicale que sur la compréhension de la composition de l'univers lui-même. Les tensions sociétales, bien perceptibles dans les traités de musique de Fludd, montrent qu'au delà de la pratique musicale, c'est une conception scientifique générale, médicale et philosophique qu'engage la pensée musicale du début du XVII siècle.

owards the end of the sixteenth century, a renewed interest in occult
philosophies prompted the revival of Neoplatonic and humanistic thought in many important European courtly circles, particularly those in which the magical properties of music and medicine were taken seriously. In courts such as that of the landgrave Moritz "the Learned" of Hesse-Kassel (r. 1592-1627), himself a skilled amateur musician, physicians and musicians alike were interested in exploring the relationships between the humours of the body and the musical modes, the affinity between the intangible human spirit and 
musical air, and the intimate link between the harmony of the body and the ascent of the soul. ${ }^{1}$ The appeal of occult philosophy for many high-ranking patrons in late Renaissance Europe is related to the humanist desire to uncover the writings of Antiquity: the promise, in the form of a unified framework of magic and natural philosophy, of higher forms of knowledge, revealing the key to unimaginable power.

The turn of the seventeenth century also saw a major revision in the relationships between magic and nature and mathematics and physics. Prior to the writings of Johannes Kepler (1571-1630), Marin Mersenne (1588-1648), and eventually Isaac Newton (1642-1726/7), the application of mathematics to the physical world - the hallmark of the modern scientific method-was by no means commonplace. The laws governing nature and the organization of the physical world were understood to be within the domain of natural magic: the realm of the philosopher as opposed to the mathematician. ${ }^{2}$ The fundamentally different worldviews of Kepler and Newton completely overturned the precepts of Aristotelian physics and divided the disciplines of natural philosophy and scientific inquiry. The eventual discrediting of occult philosophy resulted in the redefining of "magic" - from the essence of the universe to mere trickery.

Music played an important role in the scientific debates of the time. As an entity both mathematical and physical, theoretical as well as practical, music has been interpreted through the ages as an essential key to understanding the universe, both metaphorically and literally. But just as the fields of natural philosophy, magic, and medicine are in many ways foreign to our modern disciplines of science and medicine, the music so central to these discourses was almost always inaudible. Inaudible music (i.e., the harmonic fabric of the universe and the analogous harmony of the human body) is thus as important to the history of the Renaissance as audible music (i.e., the performance and composition of art music). To illustrate, I will take as examples the work of two important figures in intellectual history: Renaissance Neoplatonist Marsilio Ficino (1433-99) and his advocate in the seventeenth century, the English physician and polymath Robert Fludd (1575-1637). The musical cosmology promoted by Fludd shows the pervasive influence of Ficino's theories on music,

1. Bruce T. Moran, The Alchemical World of the German Court: Occult Philosophy and Chemical Medicine in the Circle of Moritz of Hessen (1572-1632) (Stuttgart: F. Steiner, 1991), 11-24 and 107-11.

2. Penelope Gouk, "The Role of Harmonics in the Scientific Revolution," in The Cambridge History of Western Music Theory, ed. Thomas Christensen (Cambridge: Cambridge University Press, 2002), 224. 
medicine, and astrology as late as the seventeenth century. Once one concedes that composition and practical performance represent only one part of musical thought in the late Renaissance, it becomes clear that music once had a central place in the realms of medicine and mathematics, and that the study of this history reveals a broader and richer context for understanding sound culture in early modern Europe. ${ }^{3}$

Fludd's musical writings attracted attention-both positive and negative-from his contemporaries, and, more recently, from modern scholars. ${ }^{4}$ A practising Ficinian physician, Fludd held a Neoplatonic understanding of the cosmos that did not accord with the more "progressive" theories of other early seventeenth-century scientists. Despite, or perhaps because of this, Fludd was engaged in scientific polemics with such prominent figures as Kepler and Mersenne. Although they dismissed Fludd's preoccupation with light and darkness as mere imagery, both scientists took the physician seriously enough to respond to him many times in writing, as will be seen. ${ }^{5}$ It is important to note that in these polemics Fludd's view is the more traditional one, based on the authority of ancient and Renaissance writers, and one that intrigued his aristocratic patrons. To be sure, the mathematically-conceived cosmology of Kepler and later Newton eventually replaced Aristotelian and Neoplatonic

3. (Relatively) recent research through NASA has revealed that sound can, and does, exist in space. Visit the NASA website for a recording taken of the planet Jupiter: http://solarsystem.nasa.gov/galileo/ sounds.cfm. It would seem Kepler and Fludd may have agreed on something after all.

4. Especially in the scholarship of Peter Hauge and Penelope Gouk.

5. Fludd enjoyed the favour of King James I of England, receiving commissions to create bizarre automata for the pleasure of the court. Nevertheless, his relationship with the College of Physicians in London was at times precarious. The Annals from 21 March 1608, the date of one of Fludd's examinations for admittance as a Fellow of the College, describes Fludd's attack on the cosmological beliefs of one of the censors, also providing an interesting account of Fludd's comportment: "Dr Fludd, who already had been selected to be numbered among the Candidates, conducted himself so insolently that everyone was offended, and was therefore rejected by the President with the warning that if he is to continue to practice without a license he should take great care (Dr Fludd, qui jam in Candidatorum numerum erat cooptandus tam insolenter se gessit, ut omnes offenderantur, rejectus est itaque a $\mathrm{D}^{\circ}$ Praesidente cum admonitione, ut sibi, si sine Licentia practicare pergeret, diligenter caveret)"; see William Munk, The Roll of the Royal College of Physicians (London: Longmans, Green, 1861), 142. According to Geoffrey Keynes, William Harvey was also present at this meeting; see Geoffrey Keynes, The Life of William Harvey (Oxford: Clarendon Press, 1966), 135. In 1618, Fludd was eventually to be elected censor of the College of Physicians. 
conceptions of the universe in the mainstream, but the matter was not yet entirely resolved in the early seventeenth century. Although it is tempting to see the redefinition of scientific inquiry as having rendered obsolete the older modes of thought in Renaissance Neoplatonism, it is clear not only that magic and the occult persisted in scholarly books during the first half of the seventeenth century, but that these studies too witnessed a shift from theory to practice. Despite the fact that the works of writers like Ficino and Fludd did not "win" a place in the evolution towards the modern scientific method, their books point to a paradigm shift that occurred in learned circles that would have fundamental consequences in the fields of arts and science. Furthermore, the study of such intriguing works of philosophy and magic creates for the modern scholar a space for unexpected creativity, open-mindedness, and a reconsideration of what is true and what has been proven false. Penelope Gouk, for instance, sees the marginal place of seventeenth-century occultism as "a liminal space [...] where it is impossible ever to demarcate clearly between true and false beliefs, between good and bad practice, between genius and the charlatan."

Fludd's musical writings are anything but ordinary. ${ }^{7}$ Most music theory books from England at the time fell clearly within the realm of practical music, dealing primarily with musical rudiments and the rules of composition. English authors who published music theory were usually music masters themselves and their books often had "a strong predilection for simplicity and brevity," seen readily in such titles as Thomas Morley's A Plaine and Easie Introduction to Practical Musicke (1597) and Elway Bevin's Briefe and Short Instruction of the Art of Musicke (1631). ${ }^{8}$ Although speculative musical topics were not entirely

6. Penelope Gouk, Music, Science and Natural Magic (New Haven: Yale University Press, 1999), 14.

7. Fludd's musical writings do not represent the most novel or progressive practices in music theory and composition, nor do they describe aspects of music-making that led to the innovations that frame the history of music in the early seventeenth century, namely, the defining genre of opera. Fludd's musical understanding of the cosmos arises from a very different societal milieu, one that did not share the practical goals of the "Florentine Camerata" of late sixteenth-century Florence, for example-even if it, too, was based upon the revival of ancient philosophies and ways of thinking about music.

8. Rebecca Herissone, Music Theory in Seventeenth-Century England (New Haven: Yale University Press, 1999), 1. See also Thomas Morley, A Plain and Easy Introduction, ed. R. Alec Harman (New York: W.W. Norton, 1953), and Elway Bevin, Briefe and Short Instruction of the Art of Music, ed. Denis Collins (Aldershot: Ashgate, 2007). 
absent from English music books, these treatises were, as Rebecca Herissone notes, "rarely Boethian in character." In the annotations to his Introduction to Practical Music (1598), Morley distinguished between the two forms of musical inquiry:

Speculative is that kinde of musicke which by Mathematical helpes, seeketh out the causes, properties, and natures of soundes by themselves, and compared with others proceeding no further, but content with the onlie contemplation of the Art, Practical is that which teacheth al that may be known in songs, eyther for the understanding of other mens, or making of one's own. ${ }^{10}$

Despite the abundance of manuals and instruction books on music published in England during the seventeenth century, the more traditional discipline of speculative music-that is, writings with a focus on the underlying physical causes of musical vibration as well as the mathematical foundations of musical sounds-continued to be explored by academics and scholars. These books were typically written either by educated gentlemen of rank, like Fludd, who pursued philosophical knowledge for private interest, or by academics who held university posts in mathematics, as was increasingly the case later in the century. ${ }^{11}$ Fludd's position is not easy to define; instead of falling clearly into one category of early seventeenth-century writers on music-either the practitioner writing instruction manuals, the progressive academician promoting the modern scientific method, or the gentleman of the court for whom science and music were private pursuits-Fludd moves among all three. He is at once a university-educated academician, a medical practitioner, and a courtier.

Unlike his English contemporaries who avoided these subjects altogether, Fludd retained the notions of musica mundana, the inaudible music of the spheres, and musica humana, the analogous proportion and harmony of the human body. These ideas derive primarily from Boethius's treatise, De institutione musica, of the sixth century: the fundamental scholastic text for

9. Herissone, 1.

10. Thomas Morley, “Annotations," in idem, A Plaine and Easie Introduction to Practicall Musicke (London: By Peter Short, 1597), 2.

11. Gouk, Music, Science and Natural Magic, 25. 
the study of speculative music at medieval universities. ${ }^{12}$ Boethius's text was influential for its thorough explanation of musical principles and the harmony of the universe, and also because it provided the formal model for future writings in the discipline of speculative music. Indeed, Fludd's De templo musicae and De musica mundana are faithful to Boethius's example in their form of exposition and mode of argument. Although Boethius's treatise remained on the university curriculum well into the Renaissance, medieval theoreticians of music had, since the age of high scholasticism, shown much sceptical resistance to the notions of musica mundana and musica humana, expressing concern for the disregard of the practical problems of notation and performance faced by the practising musician in traditional speculative texts.

Many musical books from the Middle Ages, even the Ars Nova treatise of about 1322, began with Boethius's standard explanation of the threefold classification of music: musica mundana, humana and instrumentalis. ${ }^{13}$ By the fourteenth century, however, Boethius's form of musical exposition had been abandoned by most writers. Johannes de Muris, for example, a theoretician who had close ties to the "English nation" at the University of Paris, ${ }^{14}$ opens his Notitia artis musicae (1319/21) with: "Ictus non fit sine motu, ergo neque sonus absque motu est. Est igitur sonus fractio aeris ex impulse percutientis ad percussum. Nam impossible est, cum sit unum solum, fieri sonum" ("no striking [ictus] can occur without motion; therefore, neither can there be sound without motion. Hence, sound is a disturbance of the air from the blow [impulsus] of a thing that strikes against a thing struck. For it is impossible that sound occurs when there is only one thing"). ${ }^{15}$ By beginning his treatise

12. See Anicius Manlius Severinus Boethius, Fundamentals of Music, trans. Calvin M. Bower, ed. Claude V. Palisca (New Haven: Yale University Press, 1989).

13. Although the Ars Nova treatise, which contained many of the most significant innovations in the field of musical notation, was thought to have been written by the teacher and composer Philippe de Vitry, Sarah Fuller has shown that there is in fact no unified text called the Ars Nova; rather, it exists in fragments in a series of manuscripts chronicling the teachings of Philippe de Vitry, likely written by many of his students. See Sarah Fuller, "A Phantom Treatise of the Fourteenth Century? The Ars Nova," The Journal of Musicology 4 (1985-86): 23-50.

14. See Joseph Dyer, "Speculative 'musica' and the Medieval University of Paris," Music \& Letters 90 (2009): 177-204.

15. Johannes de Muris, "Notitia Artis Musicae," in Jean de Murs: Écrits sur la Musique, French trans. Christian Meyer, English trans. Andrew Hicks (Paris: CNRS Editions, 2000), 60-61. Muris here draws on Aristotle's De anima, $419 \mathrm{~b} 9 \mathrm{ff}$. 
in this way, Muris reinforces a physical understanding of sound and discards the standard Boethian division of earthly and celestial music, implying that because the music of the spheres is inaudible, it cannot be classified as a form of sound.

Despite the long-standing English tradition of applied mathematics and music theory, especially at Oxford, Fludd takes a fundamentally different approach in his encyclopedic writings without displaying any influence of the major important advances of the early seventeenth century. His reintroduction of Boethian principles as late as the seventeenth century in itself demonstrates Fludd's detachment from dominant trends in English music theory. His conceptualization of the universe is decidedly Aristotelian in its implacable distinction between mathematics and physics, and Neoplatonic in its preoccupation with the soul's ascent from a state of imperfection towards the unity of God. ${ }^{16}$ This, in combination with Fludd's deliberate effort to connect music and the cosmos with the harmony and health of the human body, brings him closer to Renaissance philosophers-especially to Marsilio Ficino, writing nearly 150 years earlier-than to his immediate contemporaries. Fludd's interpretation of music in the context of the macrocosm of the universe and the microcosm of man harkens back to the early medieval theoreticians of music, bypassing the increasingly mathematical conception of time and music of the later scholastics. Fludd's revival of the early medieval speculative

16. Precedents for a fundamentally practical approach to the study of physical phenomena in England can be traced back to the scholastics, notably the mathematical innovations of the Oxford Calculators, also known as the "Merton School." On this topic see Edith Sylla, "The Oxford Calculators," in The Cambridge History of Later Medieval Philosophy, ed. Norman Kretzmann, Anthony Kenny, and Jan Pinborg (Cambridge: Cambridge University Press, 1988), 541-63. During the early fourteenth century, a group of Oxford mathematicians including Thomas Bradwardine and John Dumbleton were credited with developing practical theories of acceleration and diminution: mathematical theories in physics that would prove to be crucial in the scientific revolution of the following centuries. Indeed, the origins of distinctly anti-Aristotelian tendencies in the disciplines of physics and, pertinently, music theory can be found in the work of English scholars in the latter part of the Middle Ages. See Nancy Van Deusen, Theology and Music at the Early University: The Case of Robert Grosseteste and Anonymous IV (Leiden: Brill, 1995). Many of the most important innovations in the field of musical notation-from a contextual system of signs that served merely to indicate the flow of time in circular perfections, to a system of arbitrary signs that divided musical time infinitely_can be connected to this type of scientific inquiry, one that is based on experiment and practice. For a detailed discussion of this transition in the history of musical notation, see Dorit Tanay, Noting Music, Marking Culture: The Intellectual Context of Rhythmic Notation, 1200-1400 (Holzgerlingen: Hänssler-Verlag, 1999). 
musicians, notably of Boethius and Ptolemy, ${ }^{17}$ mirrors the Neoplatonic revival of Plotinus, Iamblichus, and Hermes Trismegistus by philosophers such as Ficino and Giovanni Pico della Mirandola (1463-94). ${ }^{18}$ Frances Yates describes this revival in the context of the Renaissance history of the hermetic tradition, referring to Fludd in particular: "At a very late date, after the Hermetica have been dated and when the whole Renaissance outlook is on the wane and about to give way before the new trends of the seventeenth century, Fludd completely reconstructs the Renaissance outlook."19

It is fitting then to see Fludd as the last of the humanists, simultaneously signalling the end of the Renaissance and demonstrating that occult philosophy and Ficinian medicine continued well into the seventeenth century. ${ }^{20}$ Fludd's polymathic conceptualization of music bears a close affinity to the writings

17. Ptolemy's Harmonics (second century) is one of the earliest sources to suggest that the structures found in music have their analogues in the soul and in the heavens. This in turn provided the precedent for future writers suggesting that astrology and music are intimately bound. See Gouk, "The Role of Harmonics," 224.

18. The Hermetic tradition, which exerted a strong influence during the early Renaissance among proponents of natural magic and esotericism, is based upon writings attributed to Hermes Trismegistus (“Thrice Great"). This tradition claims an unbroken chain of original wisdom, the priscia theologia, which dates back to the time of Abraham and Moses, through which a secret knowledge based in alchemy, astrology, and theurgy has been preserved. Through generations of initiates, including Hermes, Orpheus, and Pythagoras, this secret wisdom was expressed through symbols allegories, and other puzzles that required careful interpretation.

19. See Francis A. Yates, Giordano Bruno and the Hermetic Tradition (London: Routledge, 1964), 406. Believed in the early Renaissance to be the work of an ancient Egyptian priest, the writings attributed to Hermes Trismegistus were studied by the Swiss philologist Isaac Casaubon, who concluded in 1614 that they were likely written in the second and third centuries CE, and thus contemporary to the Neoplatonist writers such as Iamblichus and Proclus. Nevertheless, the Hermetica remained influential throughout the seventeenth century, since even Newton was hesitant to dismiss the idea that these writings represented a pure and unadulterated ancient doctrine. Casaubon, who came to England in 1610, had a curiously strong relationship with King James I, a situation that eventually resulted in his exclusion from the antiquarian circle that included William Camden, Sir Robert Cotton, and Fludd himself. See William H. Huffman, Robert Fludd and the End of the Renaissance (London: Routledge, 1988), 32-33, and Yates, Giordano Bruno.

20. Huffman, Robert Fludd. As Gouk notes, the influence of occult philosophy and of Fludd in particular can be seen in the Musurgia universalis of Athanasius Kircher of 1650. Kircher (1601/2-1680) drew on Fludd's ideas regarding music as a metaphor for the universe, mnemonic devices, and unusual and mechanical instruments; he even directly copied from Fludd's images included in Fludd, Utriusque cosmi [...] historia; see Gouk, Music, Science and Natural Magic, 101-07. See also Robert Fludd, Utriusque 
of the Renaissance Neoplatonists, Ficino in particular, and, curiously, to the medieval speculative tradition. In a humanistic fashion, Fludd's work looks back to the Neoplatonic writers of the early centuries of Christianity and reorganizes their ideas in a manner that is coloured by the revived philosophies of the Renaissance and the musical ideas of Fludd's contemporaries at the Stuart court.

\section{The Temple of Music}

Fludd began to collect materials for De templo musicae while he was still a student at Oxford in the 1590s. Although these were likely notes connected to his studies and not then intended for publication, some have suggested that he was already working on a music treatise in 1596 , the year he received his BA. ${ }^{21}$ After Fludd returned from his Continental travels, having collected more materials for his major work, he entered Christ Church, Oxford, and in 1605 received his $\mathrm{MD}$ and licence to practise medicine. By 1610 he had completed the majority of the manuscript for the first volume of Utriusque cosmi [...] historia (The history of the macrocosm). ${ }^{22}$ Fludd decided not to publish his work in England, but on the Continent. His histories appeared in print in several parts between 1617 and 1619 by John Theodore de Bry at Oppenheim, ${ }^{23}$ one of the most successful

cosmi maioris sclilicet et minoris metaphysica, physica atque technica historia, 2 vols. (Oppenhemii [Frankfurt?]: Aere Johan-Theodori de Bry, Typis Hieronymi Galleri, 1617-18).

21. Peter J. Amman, “The Musical Theory and Philosophy of Robert Fludd," Journal of the Warburg and Courtauld Institutes 30 (1967): 198-227, 205.

22. The work is divided into two volumes: the first concerns the history of the macrocosm of the universe, appearing in 1617; the second concerns man the microcosm, and was published only in part in 1619. The most important sections of Utriusque cosmi [...] historia that discuss musical subjects are De templo musicae (vol. 1, tract 2, bk 2), De musica mundana (vol. 1, tract 1, bk 3), and De integra microcosmi harmonia (vol. 2, tract 1, bk 1).

23. Yates suggests that the man who carried Fludd's text and materials for the illustrations to Oppenheim was in fact the physician Michael Maier, a notion that makes sense considering the fact that the emissary, whoever it was, added a dedication to the landgrave of Hesse, Maier's patron. This was later to become a significant dispute between the emissary, the publisher, and Fludd himself, who eventually stepped in to dedicate his work to God and James I. According to Peter Hauge, however, who bases his argument on new biographical information about Maier collected by Karin Figala and Ulrich Neumann, it is unlikely that Maier was the person. As an alternative, Hauge suggests that it may have been Justus Helt who took the manuscript to Frankfurt in order to present it to some of the publishers at the book fair in 
printing houses and engravers in Europe at the time. Fludd's decision to seek publishing opportunities abroad may have been motivated by accusations by some of Fludd's opponents that he was a magician. A certain Parson William Foster suggested that it would be impossible for either English universities or bishops to support such a publication. However, in his answer to Foster, Fludd explains:

I sent them beyond the Seas, because our home-borne Printers demanded of me fiue hundred pounds to Print the first Volume, and to find the cuts in copper, but beyond the Seas it was printed at no cost of mine, and that as I would wish: And I had 16. Coppies sent me ouer with 40 . Pounds in Gold, as an vnexpected gratuitie for it. ${ }^{24}$

Musicological scholarship in general has not looked favourably upon Fludd's De templo musicae, the most practical of his books on music. Many scholarly works that mention the subject often give the impression that Fludd's De templo musicae is completely antiquated and of no great importance in the history of music, neither in practice nor in theory. In his study of Fludd's musical philosophy Kenneth Mitchell writes: "De templo musicae, which was unknown or at least ignored by Fludd's musical contemporaries [...], can hardly be considered more than a non-musician's somewhat bungled attempt to come up with the "music treatise" necessary to complete a projected cycle of eleven treatises on

1616; see "Introduction" to Fludd, The Temple of Music by Robert Fludd, ed. Peter Hauge (Burlington, VT: Ashgate, 2011), 21. See also Karin Figala and Ulrich Neumann, "Michael Maier (1569-1622): New Bio-Bibliographical Material," in Alchemy Revisited: Proceedings of the International Conference on the History of Alchemy at the University of Groningen, ed. Z. R. W. M. von Martels (Leiden: Brill, 1990), 34-50.

24. Robert Fludd, Doctor Fludd's Answer vnto Mr Foster (London: Printed for Nathanael Butter, 1631), 21-22. Parson William Foster was a harsh critic of Rosicrucianism. Foster accused Fludd of being the author of the Rosicrucian text Summum Bonum in Foster's 1631 publication, Hoplo-crisma-spongus: or, a Sponge to Wipe Away the Weapon Salve (London: Thomas Coates for John Grove, 1631). As Marsha Keith Schuchard has noted, Foster quoted Mersenne (equally critical of Fludd) who asked how the English King James I could have suffered "such a man to live and write in his Kingdome." See Marsha Keith Schuchard, Restoring the Temple of Vision: Cabalistic Freemasonry and Stuart Culture (Leiden: Brill, 2002), 399. 
'Artes Liberaliores." 25 But Fludd did have some knowledge of musica practica considering some of the topics he chooses to discuss in De templo musicae, including the basics of musical notation and the use of consonance and dissonance in composition. However, he ignores some of the more complicated issues of musical modes and practical performance, focusing instead on the subject of music in general, the divisions of the monochord, and an inventory of contemporary, antiquated, and presumably new musical instruments. Peter Hauge notes in his introduction to the English edition of De templo musicae that Fludd tends to abbreviate his text, particularly in the fifth book on the subject of counterpoint, to such an extent that the sense is occasionally lost completely: "Fludd [...] has simply cut out the essential phrase in order to avoid a complex contrapuntal aspect." ${ }^{26}$ As mentioned, De templo musicae is not intended to guide the practitioner of music through the complexities of rhythmic proportions; rather, "[Fludd] is clearly addressing the interested natural philosopher of the intellectual elite." ${ }^{27}$ Although Fludd included material from many contemporary books on music practice and theory of the time, the practising musician would still find Fludd's treatise wanting in details and more intriguing than useful. ${ }^{28}$

What is most original about Fludd's De templo musicae is the magnificent engraving of the "temple of music" about which Fludd advises the reader, "If you examine keenly the parts of the temple, you will be a sharer of all its mysteries and an extremely experienced master in this preeminent knowledge." ${ }^{29}$ The

25. Kenneth Mitchell, "Musical Conceptions in the Hermetic Philosophy of Robert Fludd" (PhD dissertation, Washington University, 1994), 130-31.

26. Peter Hauge, "Introduction" to Fludd, The Temple of Music by Robert Fludd, ed. Peter Hauge (Burlington, VT: Ashgate, 2011), 10.

27. Peter Hauge, "Robert Fludd (1574-1637): A Musical Charlatan? A Contextual Study of his 'Temple of Music'," International Review of the Aesthetics and Sociology of Music 39 (2008): 3-29, 20-21.

28. Hauge compares Fludd's De templo musicae to English music writers such as Thomas Campion $(A$ New Way of Making Fowre Parts in Counter-Point [London: Thomas Snodham, 1613], ed. Christopher Wilson [Ashgate: Aldershot, 2003]), Thomas Morley (A Plaine and Easie Introduction, London: Peter Short, 1597), and Thomas Ravenscroft (A Briefe Discourse... in Measurable Musicke [London: Thomas Adams, 1614]), among others. Hauge also makes the observation that Fludd was one of the first writers to suggest composing counterpoint from the bass voice upwards, suggesting that although his project was quite a different one from his contemporaries, he was familiar with their work.

29. Robert Fludd, The Temple of Music by Robert Fludd, ed. Peter Hauge (Burlington, VT: Ashgate, 2011), 259. 
temple (see fig. 6.1) appears to be a mnemonic device containing myriad symbols, allegories, and depictions for various musical fundamentals and compositional techniques. The fact that Fludd chose to convey various aspects of musical fundamentals in the form of an illustration confirms his alignment with the occult tradition, where the affinity for images pointed to the mysterious and magical relationship that was believed to exist between words, pictures, and thoughts. ${ }^{30}$ As Hauge has chronicled in detail, most of the contents of Fludd's temple are drawn from other sources. For example, the well-known legend of Pythagoras at the blacksmith's is depicted in the bottom left corner of the structure, ${ }^{31}$ and the black-and-white triangle of consonant and dissonant intervals is a compositional aid that Thomas Morley had used in his A Plaine and Easie Introduction of $1597 . .^{32}$ Directly beside this, Fludd reproduces Johannes Torkesey's triangle on the combinations of perfect and imperfect mensuration. ${ }^{33}$ (See fig. 6.1.)

Other musical theoretical books of the sixteenth century, for example Stefano Vanneo's Recanetum de musica aurea (1533), also use mnemonic illustrations incorporating pillars and table-like arrangements to explain proportion and musical time. In Pietro Aron's Toscanello in musica (1539), the author uses columns to explain mensuration signs and the value of rests (see fig. 6.2). The placement of items, in this case musical rudiments and compositional

30. Robert S. Westman, "Nature, Art and Psyche: Jung, Pauli, and the Kepler-Fludd Polemic," in Occult and Scientific Mentalities in the Renaissance, ed. Brian Vickers (Cambridge: Cambridge University Press, 1984), 77-229. See also Katelijne Schiltz, Music and Riddle Culture in the Renaissance (Cambridge: Cambridge University Press, 2015).

31. A similar image of Pythagoras at the blacksmith's is found in Athanasius Kircher's Musurgia Universalis (Rome: Ludovici Grignani, 1650) within an illustration of a hydraulic organ (Musurgia Universalis, ii, 437). Indeed, Fludd was held in high regard by writers of the German baroque, including Kircher and Andreas Werckmeister (1645-1706), and it is largely through their work, Kircher's in particular, that Fludd's ideas, his automata especially, were disseminated later in the century. See Mitchell, ch. 4 and 5.

32. Hauge's research into Fludd's models for the temple of music suggests that the physician was well acquainted with writings and scientific treatises from the early sixteenth century, originating both from Italy and German-speaking lands: for example, works of sixteenth-century authors who advocated for temple-like arrangements, including Giulio Camillo's L'idea del theatro (1550) and Lomazzo's L'idea del tempio pittura (1590). Hauge, "Introduction," 5.

33. Johannes Torkesey, Trianguli et scuti declaratio, ed. André Gilles and Gilbert Reaney, Corpus scriptorium musicae (Rome: American Institute of Musicology, 1966), xii, 57. 
aids, within an architectural structure compartmentalizes information and thus renders its presentation more effective as a mnemonic aid. The technique of organizing a list of items within the "rooms" of a mental building was a common medieval memory-aid, a topic that has been discussed extensively by Mary Carruthers and Frances Yates. ${ }^{34}$ The connection between architectural structure and musical rudiments persisted through to the sixteenth century as seen in the work of Aron, suggesting that Fludd's use of a musical temple as a mnemonic device is not only an odd resurfacing of medieval conceptions of time and music in the seventeenth century, but also a continuation of traditional ways of teaching musical rudiments. ${ }^{35}$

Through the quotation, either visually or textually, of earlier writers, Fludd's temple illustration brings together aspects of medieval and humanistic thought, and also shows the influence of fifteenth-century Neoplatonism. It is significant, for example, that Fludd chose to place the god Apollo in the arched structure on the far left tower, above the monochord. In his explanation of the temple, Fludd writes:

Accordingly the learned will consider any part of this structure with eager eyes and not disregard its smallest portion, because it is moved in any part as in its whole by that harmonic soul of Apollo. And that spirit of Music, sweetly soothing and delighting the souls of living beings, is accustomed to blow through all the sinews of this structure according to the manner of Zephyr, seizing with it the desires of man and quenching the madness of the unkind Daemons with its sweetness as if suffusing them with a certain humanity. ${ }^{36}$

34. See Mary Carruthers, The Book of Memory: A Study of Memory in Medieval Culture, 2nd ed. (New York: Cambridge University Press, 2008) and Francis A. Yates, The Art of Memory (Chicago: Chicago University Press, 1966).

35. Even later in the seventeenth century, some works used illustrations to teach musical principles: for example, Charles Butler employed a mnemonic device called "A Brief Synopsis" in his Principles on Musik (London, 1636). The idea of a "temple" of music was still relevant in English music theory later in the century; in 1664, John Birchensha published a translation of Johann Heinrich Alsted's treatise on music from his Encyclopaedia (Herborn, 1630), which was published in English as Templum Musicum [...] A Compendium of the Rudiments both of the Mathematical and practical Part of Musick. 36. Fludd, The Temple of Music, 35. 
This fascinating passage speaks not only to Fludd's clear evocation of Ficino's spirit-music that "quenches the madness of the unkind Daemons," but also to the idea that this structure represents the soul of Apollo, through which blows the same spirit-music that cures and nourishes the soul. ${ }^{37}$ In the temple of music, as with his monochord, Fludd creates a symbol that conveys the mysterious nature of music and harmonic proportion, and embodies the idea of the macrocosm of the universe and the microcosm of man..$^{38}$

The appearance of Apollo, the deity who bestowed Orpheus's lyre, is even more significant in the context of Fludd's citation of Ficino, who writes of Apollo as both the lord of song and also as the god who drives away disease, regulating the soul of man and of the world through harmony and balance:

Apollo, whom the ancient theologians thought was the inventor of medicine and lord of the sounding lyre. [...] Orpheus, in his book of hymns asserts that Apollo, by his vital rays, bestows health and life on all and drives away disease. Furthermore, by the sounding strings, that is, their vibrations and power, he regulates everything. ${ }^{39}$

Ficino's reference to the "ancient theologians" gives a sense of authority and continuity to the power of Apollo who "regulates everything" by the heavenly harmonies of the universe and the tangible vibration of sounding strings. Furthermore, Apollo is, through Orpheus, the source of earthly hymns and songs that may cure disease and restore the harmony of the human body, a topic about which Ficino writes extensively. ${ }^{40}$ Fludd's choice to place Apollo at the head of his temple of music is therefore both an acknowledgement of

37. For a detailed discussion of Ficino's spirit-music see Gary Tomlinson, Music in Renaissance Magic: Toward a Historiography of Others (Chicago: Chicago University Press, 1993), ch. 4, 101-44. See also William Bowen, "Ficino's Analysis of Musical Harmonia," in Ficino and Renaissance Neoplatonism, ed. Konrad Eisenbichler and Olga Z. Pugliese, University of Toronto Italian Studies 1 (Ottawa: Dovercourt, 1986), 17-27.

38. The only other English treatise on music that refers specifically to Ficino is John Case's Apologia musices (Oxford, 1588); see Hauge, "Introduction," 8.

39. Marsilio Ficino, "De musica," in Ficino, The Letters of Marsilio Ficino, trans. members of the Language Department of the School of Economics Science, vol. 1 (London: Shepheard-Walwyn, 1975), 1:142.

40. See also Vladimir Marchenkov, The Orpheus Myth and the Powers of Music (Hillsdale, NY: Pendragon Press, 2009). 
Ficino and ancient theologians, and a synthesis of Neoplatonic philosophy and speculative music.

In the third chapter of De templo, "On the working of music on the soul and body," Fludd quotes Ficino directly, placing him side by side with Plato, with selections from the Republic, and the medieval theoretician Guido of Arezzo, author of the important treatise Micrologus (1026). Fludd lays out the greater part of this chapter in the form of a tree diagram that shows "the harmony of music according to Guido, Marsilio and Plato." In such a fashion, the reader is free to compare the views of the three different philosophers and also to recall the original context of Fludd's references by completing the sentences that he quotes only in fragments. ${ }^{41}$ The passage of "Marsilio" that Fludd quotes in this section is taken from Ficino's commentary on Plato's Timaeus, where he writes:

But musical sound by the movement of the air moves the body: by purified air it excites the aerial spirit which is the bond of body and soul: by emotion it affects the senses and at the same time the soul: by meaning it works on the mind: finally, by the very movement of the subtle air it penetrates strongly: by its contemperation if flows smoothly: by the conformity of its quality it floods us with a wonderful pleasure: but its nature, both spiritual and material, it at once seizes, and claims as its own, man in his entirety. ${ }^{42}$

Music, as moving and living air, resembles an ethereal spirit that may nourish the spiritus, the bond between body and soul, to simultaneously cure the body of melancholy and other ailments and fortify the intellect by its proportion and by its marriage to poetry in monodic song. When the soul receives sweet harmonies and numbers through the ears, "by these echoes [it] is reminded and aroused to the divine music which may be heard by the more subtle and penetrating sense of mind." ${ }^{43}$

41. In his tree diagram, Fludd summarizes the views of Plato, Ficino, and Guido by duplicating their words in a point-form list. Fludd, The Temple of Music, bk 1, ch. 3, "On the working of music on soul and body," $44-45$.

42. Ficino, Opera Omnia, 1453 (Comm. in Tim., fol. 28). Quoted and translated in Walker, Spiritual and Demonic Magic: From Ficino to Campanella (Notre Dame: University of Notre Dame Press, 1975), 9. 43. Marsilio Ficino, "De divino furore," in The Letters of Marsilio Ficino, 1:45. 
Ficino explains in his commentary on the Timaeus the necessary connection between music and medicine, the reason why Apollo is god of both harmony and healing:

For certain diseases both physical and mental are said to be miraculously cured by certain harmonies, so that it is no wonder that the sages of old attributed the origin of both medicine and music to the same source, namely, the god Apollo. For each is a medicine. But one cures the soul from the body, while the other cures the body from the soul. The ancients quite rightly attributed prophecy, too, to Apollo, the source of melody. For melody alone draws the mind back from all that would draw it away, and draws it together into itself, into a kind of hearing, if I may so call it, by which are perceived not only the notes but also the ratios of notes. ${ }^{44}$

Fludd found in Ficino the justification not only for the idea of "silent hearing," of a recollection of the divine harmony through which the soul of man passed before coming into his body, but also for the symbol that unites music, medicine, and prophecy: the sun-god Apollo. As the pillar of Fludd's temple, Apollo represents at once the macrocosmic world-soul and the microcosmic soul of man; he embodies the solar origins of the soul and provides the musical means to heal it. As Ficino writes, "The highly musical hymn of Apollo [is] the origin both of the world-soul and of the body." ${ }^{35}$ Music revitalizes and nourishes the human soul by virtue of the fact that it represents both the foundational structure of the cosmos-analogous to the soul-and the airy protean quality of the spiritus - the bond of body and soul.

In his own time, Fludd was not isolated in his preoccupation with the relationship of man, music, and the heavens. The subjects of astrology and the idea of man as the microcosm of the universe were, among some of Fludd's continental contemporaries, subjects of great interest that resulted in a revival of the ideas of the physician Paracelsus (1493-54), and the English scholastic Roger Bacon (ca. 1214-92), with whose work Fludd was familiar. ${ }^{46}$ The

44. Marsilio Ficino, All Things Natural: Ficino on Plato's Timaeus, trans. Arthur Farndell (London: Shepheard-Walwyn, 2010), 59.

45. Ficino, All Things Natural, 52-53.

46. The writings of Theophrastus Philippus Aureolus Bombastus von Hohenheim (1493-1541), also known as Paracelsus, on chemical medicine were widely known across Europe. Believing in an essential 
theologian from Marburg, Johannes Combach (1585-1651), whose work was strongly influenced by the ideas of Paracelsus, visited Oxford in 1609-when he became acquainted with the alchemical and astrological works of Roger Bacon. ${ }^{47}$ Combach published Bacon's works in Germany, bringing the Englishman's writings on the scientiae mediae-those sciences such as optics and music that are dual in nature since they are both physical and mathematical-to a wider European audience. ${ }^{48}$

The sympathy (akin to those of sounding strings) between the human body and the stars led many German writers such as Combach to believe, following Paracelsus, that medicines associated with certain astral bodies could have a profound effect on the internal balances of the human body. Helvig Dieterich, for example, dedicated his Elogium planetarum caelestium et terrestrium, macrocosmi et microcosmi to the landgrave Moritz the Learned of Hesse in 1627, whose court was a centre for the study of Paracelsian medicine. ${ }^{49}$ Dieterich writes that certain human diseases were astral in nature, caused by the influence of the heavens and the manifestation of planetary forces within

correspondence between the body of man and the cosmos (the microcosm and macrocosm), Paracelsus advocated for the use of medicines that would cure diseases by restoring the humoral balance of the human body. Paracelsian medicine promotes the idea that a medicament should be similar in substance to its disease, unlike the Galenists who maintained that humoral excess or deficiency should be cured with its opposite. This resounds well with Ficino's notion that illnesses should be cured with like substances, for example that music nourishes the spiritus since both musical sounds and the human spirit are made of air and thus share an affinity.

47. For more information on Combach see Strieder, Grundlage zu einer Hessischen Gelehrten), 2:244-62; 3:540-41; 8:507. The French Protestant alchemist Nicolas Barnaud (1538-1604) also published works ascribed to Roger Bacon as Sanioris medicinae, Frankfurt, 1603. Beginning in 1603, a controversy ensued in France between the medical faculty of Paris and Paracelsian physicians. See Lynn Thorndike, A History of Magic and Experimental Science (New York: Macmillan, 1929, 7:153-54).

48. Bacon's Perspectiva and Specula mathematica were both published at Frankfurt in 1614. Thorndike, 7:142.

49. Indeed, it is possible that Fludd may have visited Kassel during his continental travels. Maier, who visited England after the death of his patron Rudolph II, was Moritz's personal physician by 1619 and, according to Huffman, kept up a correspondence with Fludd, particularly regarding the connection both men had to the Rosicrucians. See Huffman, ch. 9: "The Rosicrucian Connection." Indeed, Yates has suggested that Maier may have been responsible for the publication of the Rosicrucian manifestos by the Oppenheim firm De Bry, the same printer who put forth Fludd's volumes and had strong ties with the Palatinate court; Frances A. Yates, The Rosicrucian Enlightenment (London: Routledge and Kegan Paul, 1972), 70. 
the body. The central idea that the health of the human body could be achieved only by tempering the humoral proportions of the body-proportions that were connected to the heavens by musical means-is a central tenet in both Fludd's temple of music and his monochordum mundi, discussed below. The persistence of such ideas in the thinking of many German writers, including Combach, Dieterich, and Johann Bickerus, the author of Hermes redivivus (1612) dedicated to Johann Georg, Duke of Saxony, ${ }^{50}$ suggests that Fludd's musical and medical writings were likely at home within these social circles: practising physicians, theologians, and mathematicians with strong associations to noble courts. ${ }^{51}$

Fludd's temple of music image is built to point out the connection between the astral bodies and deities of the heavens with the balance of the human body, without sacrificing their mysterious and elusive nature. Although much of the content is borrowed, the arrangement of the temple is Fludd's original creation, providing a tangible metaphor for the macrocosm and the microcosm, with the soul of Apollo as the primary locus. His symbol displays a synthesis of elements drawn from ancient writers, Renaissance Neoplatonists, scholastic speculative

50. Thorndike, 7:144. Another work similar in focus to Fludd's is the Microcosmus, hoc est, descriptione hominis et mundi (Lipsiae, 1615) of Franciscus Tidicaeus, the Danzig-born professor of medicine at Thorn.

51. The use of music as medicine persisted outside Germany as well. For example, the work of the Italian astrologers: 1) Ludovico Zacconi (1555-1627), an Augustinian Friar from Pesaro who studied composition with Andrea Gabrieli in Venice and later served at the ducal court of Bavaria for Wilhelm V. His most notable works regarding music include Prattica di musica (Venice, 1592 and 1622) and L'astrologiche richezze di Natura (Pesaro, Biblioteca Oliveriana, MSS 564); 2) Teodoro Osio (?-1699), a Milanese Pythagorean theoretician whose encyclopedic writings included the topics of music, astrology, geometry, and divination (L'armonia del nudo parlare, 1637; Schedia ad Musica, Milano Biblioteca Ambrosiana G. 136 Inf.); and 3) Pier Francesco Valentini Romano (1570-1654), the Roman astrologer from whom Kircher took material for his Musurgia universalis (402 and 584). Of particular interest are Valentini's descriptions of the use of music as medicine within Roman hospitals with every indication that these practices were commonplace. From his Compendio dell'arte essorcistica: "Circa questa particolarità cioè che la musica sia potentissima per rallegrare gl'infermi, et a questo effetto in alcuni spedali (come a Roma in quello di San Spirito in Sassia, et in quello di San Giovanni Laterano) sonarisi gl'organi, e talvolta cantarvisi; appare essere cosa certa per molte autorità di gravissimi autori, et essere cosa manifestatissima per moltissimi esempi et esperienze che se ne vedono" (Vatican City, MS Barb. lat. 4418 [1]. fol. 162). See Laurence Wuidar, Musique et astrologie après le concile de Trente (Brussels: Institut historique belge de Rome, 2008), especially chapter 4, "Écrits astrologiques de musiciens italiens du XVIIème siècle," and Robert L. Kendrick, The Sounds of Milan, 1585-1650 (New York: Oxford University Press, 2002), 101-02. 
writers, and early seventeenth-century musicians. It is perhaps not a fallacy but precisely the point that Fludd constructs in De templo musicae a completely antiquated view in comparison to other, similar treatises of the period. The brilliance of Fludd's temple lies in the fact that a mnemonic device, which looks back to the spiral-like logic of the earlier Middle Ages, provides a profoundly astute symbol of the Neoplatonic relationship between the macrocosm of the world and the microcosm of man.

\section{Fludd's monochordum mundi}

The two other significant books in Fludd's Utriusque cosmi [...] historia that relate directly to music, De musica mundana and De integra microcosmi harmonia, deal with the central image of the monochord. Although the subject of the monochord had by the seventeenth century all but disappeared from treatises on practical music, it remained an important point of interest for writings by natural philosophers. ${ }^{52}$ The origins of the monochordum mundi are explained in De musica mundana by the theory of the interpenetrating pyramids, which Fludd calls "the principal key to his philosophy" (see fig. 6.3). ${ }^{53}$ As Fludd explains, the opposing principles of forma and materia, that is, light and darkness, were separated in the process of creation though they were at one time indistinguishable. In his model, the "formal" pyramid originates in the divine light of God and reaches its summit in the centre of the darkness of earth. Conversely, the "material" pyramid finds its base in the darkness of the world and reaches up towards the divine light. Thus, the two interlocking pyramids are together a symbolic representation of the proportional increase and decrease of forma, from the unity of the divine to the multiplicity of the earth, in a cosmic hierarchy. ${ }^{54}$

Fludd takes this polarity as the basis for his monochordum mundi, (see fig. 6.4), which shows the harmonic proportionality of the universe by extending the string of the monochord, the materia, up towards the anima mundi and

52. For a detailed discussion of the monochord in the context of the history of music theory see Peter Hauge, "English Music Theory c. 1590-c. 1690: The Modal Systems, Changing Concepts, and the Development of New Classification Systems" (PhD dissertation, City University of London, 1997).

53. Fludd describes this theory in the treatise "De speculative Pyramidum Metaphysicae et physicae Scientia," in Fludd, Utriusque cosmi [...] historia, book 2, tract 1, pp. 171-91.

54. Amman, 200. 
the essential light. ${ }^{55}$ The Empyrean and the material world are constructed analogously in the form of two octaves, indicated by the letter names on the soundboard of the monochord. ${ }^{56}$ The earthly and divine octaves are joined at the sun, and subdivided into smaller intervals, referring to the earthly elements in the lower section of the image, up through the signs of the planets and astrological signs in the ethereal level, and finally the different layers of the Empyrean. As Peter Amman has beautifully put it, "the uncreated divine harmony is united with the created harmony by the insoluble tie of the perfect octave [...] thus the octave is the tie by which God linked the music of His life and light to that of His creatures." 57

Fludd refers to God as the pulsator monochordii, depicting the hand of God as the "tuner" of the monochord of the world. He describes God as the player of musica humana, the internal harmony of the soul of man, suggesting that the string itself, which is both divine and earthly, can be understood as a symbol for Christ, one who shares in a dual nature being both God and man, and whose influence is regulated, or "tuned," by God the father. Fludd's theory of the monochord provides a tangible symbol for his musical theology. As God tunes the string of the monochordum mundi, He regulates the celestial balance between heaven and earth. ${ }^{58}$ In his commentary of the monochord engraving Fludd writes:

In this picture we see the miraculous harmony in which the two extremes, the most valuable and the meanest, are chained together and are in harmony; we see how the intermediary world spirit, the vehicle of the souls, is the tie which links the two extremes in joyful harmony and we see how God is the player of musica humana, the player of the string of the monochord, the inner principle which, from the centre of the whole, creates the consonant effects of life in the microcosm. The string which by its vibration spreads the luminous effect of the Inspirer through

55. "This vivifying Catholic spiritual or angelic presence is called the Anima Mundi or Soul of the World by the Platonists, Metatron by the Cabalists, and is also called the Donum Dei, the Gift of God, mens divina or the emanation of the Word," Huffman, 109.

56. Fludd uses the Greek terms diapason for the perfect octave, diapente for the perfect fifth, and diatessaron for the interval of a perfect fourth.

57. Amman, 208.

58. Amman, 224. 
macrocosm and microcosm as accents and sounds of love, as it were, is the luminous spirit which participates in the two extremes and which joins them together. This string equally denotes the system of notation, or staff, in man by which the soul descends from the higher spheres and reascends towards them after death, when the ties of the body, the meanest of all places, have been dissolved. ${ }^{59}$

Although he draws heavily from Ficino and also from Cornelius Agrippa in this section, Fludd never mentions any particular work of either author. Instead, Fludd repeatedly confesses his admiration for the work De harmonia mundi (1525) by the Venetian Franciscan Francesco Giorgio (1466-1540). ${ }^{60}$ According to Yates, it was though works like Giorgio's-which is itself quite similar to Fludd's in its musical harmonic universe and employment of the monochord symbol-that Renaissance Neoplatonism reached England in the late sixteenth century. ${ }^{61}$ As Fludd was a renowned Cabalist and hermetic scholar, it is no surprise that he would openly express admiration for Giorgio's cosmology, from whom he drew the idea of God the arch-musician or summus moderator, the order of the three worlds, and the term monochordum mundi. Indeed, the passages of Monochordum mundi in which Fludd discusses Plato's theory and its later manifestations in the writings of Proclus are occasionally copied verbatim from Giorgio's De harmonia mundi. ${ }^{62}$

For Giorgio, as for Fludd, the importance of all-embracing mathematical analogies was paramount in the construction of his book on music. De harmonia mundi is composed in three cantica, each divided into eight toni, creating a book built entirely upon a musical metaphor. ${ }^{63}$ Again, like Fludd, Giorgio's musical analogies are not truly mathematical but rather proportional, in the sense that the author's purpose is to prove not that every aspect of the universe is built on precise and calculable intervals, but that the common characteristics of number and ratio between man and the heavens can reveal the manifest

59. Fludd, Utriusque cosmi [...] historia, vol. 2, tract 1, 274-75. Quoted and translated in Amman, 209.

60. Giorgio, De harmonia mundi.

61. Giorgio's De harmonia mundi is found in the famous occultist John Dee's afore-mentioned library catalogue from 1583. Frances A. Yates, Elizabethan Neoplatonism Reconsidered: Spenser and Francesco Giorgi (London: The Society for Renaissance Studies, 1977), 5.

62. Amman, 221.

63. Walker, Spiritual and Demonic Magic, 116. 
analogies between them. Herein lies one of the greatest weaknesses of both Giorgio's and Fludd's collage-like and all-encompassing views of the universe: they both present a somewhat disorganized and jumbled worldview, claiming to include every aspect necessary in constructing a complete philosophy. As D. P. Walker has amusingly put it, "Ficino's analogies between cosmic, musical and human spirits led to magic, Kepler's mathematical ones to science; Giorgio's and Fludd's were not meant to lead anywhere." ${ }^{64}$ But perhaps Fludd's work was not such a dead end as Walker suggests, if not for where it led, but rather, for what it prompted.

\section{Music, physics, and mathematics}

As mentioned, the intended audience for Fludd's writings on music was not contemporary practising musicians, who seem to have completely ignored Fludd's work, but rather natural philosophers, physicians, and members of the intellectual elite. Fludd attracted the criticism of scientists such as Kepler and Mersenne, as opposed to musicians and composers. Until the time of Newton, ideas of "science" could not be separated from the magical processes that governed the natural world. For a modern reader trying to make sense of the confusing philosophy of a writer like Fludd, the locus of the problem is in the applicability of mathematical explanations-which are by nature abstract and infinitely precise-to the phenomena of the natural world, which are often imprecise or imperfect physical processes. Since Antiquity, the field of musical harmonics was understood as the study of the mathematical relations that underlie the structure of music, the key point being that proportional mathematics is distinct from applied mathematics (the application of mathematical equations to physical phenomena). Only later in the seventeenth century, when the mathematical relations of sound were complemented by experimental evidence, was the study of musical harmonics transformed into the field of acoustics, a thoroughly mathematical discipline. ${ }^{65}$

Although so much of Fludd's conception of man and the universe is rooted in Neoplatonic philosophy, his firm separation of physics and mathematics is demonstrably Aristotelian. This is a particularly significant point in the 
discussion of music which can be seen either as primarily proportional in nature - as in Boethius and Fludd-or as a mathematical complex that can be divided infinitely —as in many of Fludd's predecessors including Johannes de Muris (ca. 1290-ca. 1355), Robert Grosseteste (ca. 1168-1253), and Roger Bacon (ca. 1214-92). ${ }^{66}$ For Fludd, the study of music was less a matter of mathematical calculations and more one of physical relations, whose causes could reveal the inner secrets of the universe. Indeed, Aristotelian philosophy provided many elements of the magical worlds of writers like Fludd, including a strong belief in the influence of heavenly bodies on the activities and physical wellness of man, and in the relationship between the macrocosm and the microcosm. ${ }^{67}$

Although Fludd's "physical" rather than "mathematical" view of music puts him at odds with his English contemporaries and predecessors, it is a point of great importance for the relationship between Fludd's and Ficino's ideas about music. For Ficino, the mysteries of harmonics are intimately connected to the harmony of the soul and consequently to the bond between man and God. Therefore, music lies firmly in the realm of physics and metaphysics, unquantifiable and absolute. In his commentary on Plato's Timaeus, Ficino writes:

our Plato has described the effective, preserving, and moving soul of all natural beings as consisting of musical numbers and ratios in particular-I do not mean mathematical numbers, as some falsely claim, but the ideal and metaphysical ratios of numbers. [...] For our soul contains all the

66. Strongly influenced by the theories of the Oxford Calculators mentioned in the introduction, Grosseteste and his pupil Bacon placed music at the head of the quadrivium and strongly advocated for the experimental scientific method. Their ideas dismantled the primarily Aristotelian concept of time, perfection, and measured music. They set the precedent for musical scholarship in England-and, through their influence on theorists like Johannes de Muris, advanced the idea that mathematics could illuminate natural phenomena. In their view, the reality that the physical nature of music has necessary limits did not hold any bearing on the fact that a new "linear" concept of time could suggest the idea of infinity. See Tanay, Noting Music; Jeremy Yudkin, “The Influence of Aristotle on French University Music Texts," in Music Theory and its Sources, ed. André Barbera (Notre Dame: University of Notre Dame Press, 1970), 173-89; and Van Deusen, Theology and Music at the Early University.

67. Brian Copenhaver, "Astrology and Magic," in The Cambridge History of Renaissance Philosophy, ed. Charles B. Schmitt and Quentin Skinner (Cambridge: Cambridge University Press, 1988), 1: 287. 
proportions contained in the world-soul. For this reason, both in the world-soul and in our own the ratios are not mathematical but natural. ${ }^{68}$

This issue of whether or not music, and indeed the motion of the heavenly bodies, should be subject to the accuracy of mathematical calculation is at the root of the controversy between Fludd and Kepler.

Although Kepler's ideas are firmly rooted in the modern methods of observational and experimental science, it is important to remember, as William Huffman writes, that "both men inhabited a world where physics, ancient metaphysics and religion had not yet become separated." ${ }^{69}$ In other words, the physical world could only be made sense of in the context of a divinely ordered universe. Kepler actually notated distinct chant melodies for each of the planets based on his observations: tunes that corresponded in range and ambitus to his observations of their orbits. ${ }^{70}$ The idea that celestial harmony is a real and observable phenomenon and not an abstraction is remarkable, suggesting a mystical leaning in Kepler's work. This may be readily observed in his idea that the planets perpetually orbit the sun by way of their eternal melodies; planetary motion is in this case synonymous with music. Nevertheless, Kepler takes great issue with Fludd's De musica mundana in his appendix to Harmonice mundi (1619), in which he makes clear that his worldview, based primarily on actual planetary motion, is vastly different from Fludd's, whose preoccupation with light and perfection is, to Kepler, useless symbolism.

In his Harmonice mundi, Kepler intended to prove that the harmonies of the heavens were real, observable, and measurable as true quantitative proportions. Whereas Fludd's musical conception of the entire universe was completely unverifiable, with its regions of elements, planets, and angels, Kepler's ideas promoted an interest in the real mathematical proportions of planetary movement. One of Kepler's primary criticisms of the physician was the fact that he equated musical proportions with motion, dictated by degrees of light or darkness. For Fludd, the "movement" of interest was that of the soul, ascending and descending the Neoplatonic ladder of light and darkness by way

68. Ficino, All Things Natural, 53.

69. Huffman, 56.

70. Wuidar, 41. See also Walker, "Kepler's Celestial Music," Journal of the Warburg and Courtauld Institutes 30 (1967): 228-50. 
of musical intervals. The meaning of "mathematics" and "movement" is thus for the two philosophers very different. Kepler writes, "but I have set out units which are natural, that is to say the two extreme motions of each planet [...] expressed by their nature in their definite quantities, in which to seek harmonies. He [Fludd] seeks harmonic proportions in degrees of darkness and light, without respect to any motion: I seek harmonies only in motions." ${ }^{\prime 11}$ Because for Fludd there is an essential difference between natural and mathematical things, the "motion" and "proportion" of the musical universe is primarily a matter of physics, and, in typical Neoplatonic fashion, is concerned with the ascent from imperfection to perfection. Therefore, the motions of the heavens, and by consequence the movements of the soul, are not subject to the specifics of mathematical quantification, which are essentially vulgar, abstract, and mere accidental qualities of physical phenomena. ${ }^{72}$ Disregarding this distinction of mathematics and physics and advocating for a quantifiable universe, Kepler rejects as meaningless Fludd's traditional number symbolism from which he derived the harmonic proportions of the world.

In his response to Kepler, contained in the treatise Veritatis proscenium $(1621),{ }^{73}$ Fludd reiterates his position on the applicability of mathematical calculation to physics and accuses Kepler of considering only the material half of the universe: materia in Fludd's dual-pyramid model of a Neoplatonic world. "That is the whole trouble," Fludd writes, "Kepler is concerned with the

71. Johannes Kepler, The Harmony of the World, trans. E. J. Aiton, A. M. Duncan, and J. V. Field (Philadelphia: The American Philosophical Society, 1997), 507-08. Kepler here continues, "He [Fludd] plucks out a few trivial consonances, and elicits them from the mixture of his pyramids, from which he conjures up the cosmos privately depicted in his mind, or deems them to be represented by it. I have demonstrated that the whole body of harmonic combinations, with all its parts, is found in the planets' own extreme motions, according to measures which are certain and derived from astronomy. Thus for him his conception of the cosmos, for me the cosmos itself, or the real motion of the planets in it, are the basis of the cosmic harmony." See also Kepler, "Harmonice mundi," in Johannes Kepler, Gesammelte Werke, ed. M. Caspar, vol. 6 (Munich: C. H. Beck, 1940), 6:376: "At mihi unitates naturales, bini sc. motus planetarum extremi (seu diurni seu horarij, nihil interest) expressi à naturâ in certas suas quantitates, sunt propositi, in quibus Harmonias quaeram. Ille in tenebrarum et lucis gradibus, quaerit proportiones Harmonicas, nullo respectu alicujus motus: Ego Harmonias non nisi in motus quaero."

72. Fludd, Veritatis proscenium (Frankfurt: De Bry, 1621), 26.

73. The Veritatis proscenium was published as an appendix to Fludd, Utriusque cosmi [...] historia, vol. 2 , tract 2 . 
external movements of things, but I with the internal and essential processes of Nature." ${ }^{74}$ To this, Kepler responds,

notice also that he [Fludd] takes great delight in topics which are hidden in the darkness of riddles, whereas I strive to bring topics which are wrapped in obscurity out into the light of understanding. The former is familiar to chemists, Hermeticists and Paracelsians; the latter is considered their own by mathematicians. ${ }^{75}$

Here, Kepler not only concedes that the scholar who studies physical phenomena is primarily a mathematician, but also makes it clear that to him, alchemists, Hermeticists, and Paracelsians have no business studying the motion or nature of the heavens. Predictably, Fludd responds to this by stating poignantly, "the ordinary mathematicians deal with the shadows of quantities, the chemists and Hermeticists, however, grasp the true essence of natural things." 76

In his musical conception of man and the universe, Fludd combines an Aristotelian view of physics with a Neoplatonic hierarchy of macrocosm and microcosm. Furthermore, Fludd joins this worldview, through the magical properties of music, to medicine; the harmony of the universe brings light to the world, and the harmony of earthly music restores health to the soul. In this respect, Fludd is following Ficino, who wrote in his letter De musica, "Plato and Aristotle taught, as we have often found from our own experience, that serious music maintains and restores this harmony to the parts of the soul, while medicine restores harmony to the parts of the body." ${ }^{\prime 7}$ Apollo, as the sunsymbol and origin of light, brings harmony to the world through the music

74. Fludd, Veritatis proscenium, 36: "Sed hic tota latet difficultas, quod ipse [Kepler] motus rei naturatae exteriores excogitat, ego actus internos et essentials ab ipsa natura profluentes considero," trans. Amman, 213.

75. Kepler, The Harmony of the World, 505. See also Kepler, Gesammelte Werke, 6:374: "Videas etiam, ipsum plurimùm delectari rerum aenigmatibus tenebrosis, cùm ego res ipsas obscuritate involutas in lucem intellectus proferre nitar. Illud quidem familiar est Chymicis, Hermeticis, Paracelsistis; hoc proprium habent Mathematici."

76. Fludd, Veritatis proscenium, 12; "Nam mathematicorum vulgarium est circa umbras quantitativas versari; Chymici et Hermetici veram corporum naturalium medullam amplectuntur," trans., Amman, 212.

77. Ficino, "De musica," in Ficino, The Letters of Marsilio Ficino, 1:142. 
of the spheres, and heals the body in the analogous songs and poems of man. Thus Fludd is concerned not with the mathematically quantifiable movement but rather with "an ascent from imperfection to perfection, from impurity to purity, from the depth to the summit, from crudeness to full maturity, from darkness to light." 78

Fludd's other most severe critic was Mersenne, whose denunciation of all forms of magic in his natural philosophy led him to discredit Fludd's work in nearly every respect. ${ }^{79}$ Like Kepler however, Mersenne was in favour of a universal harmony and believed strongly in a musical basis for the construction of the world. Shortly before the publication of his Harmonie universelle (1636), Mersenne published a work entitled Les Préludes à l'Harmonie universelle qui nous fournissent un témoignage clé sur la relation entre astrologie et musique (1634). ${ }^{80}$ This book, meant for readers from a large spectrum of disciplines such as astrology, medicine, and theology, although curiously not for musicians or composers, is divided into a set of eleven questions, or preludes, which give the form of the book a distinctly musical character. Despite his criticism of Fludd, Mersenne's worldview was closely connected to the magical tradition, perhaps explaining his passionate denial of it. Mersenne was by no means an isolated progressive scientist, advocating for modern scientific methods against the backward-looking magicians, but was rather deeply connected with the theological and political issues arising from his Catholicism and his complex relationship with the work of Protestant scholars. These musical and scientific fields of study often reveal unexpected connections between Protestant and Catholic thinkers, and also demonstrate that these ideas traversed religious boundaries to a surprising extent. While Mersenne necessarily "disapproved of [Francis] Bacon as a heretic," there are nonetheless close similarities between Mersenne's ideas and those of Bacon, outlined in his The Advancement of Learning (1605). ${ }^{81}$

\section{Amman, 212.}

79. William L. Hine, "Mersenne: Naturalism and Magic," in Occult and Scientific Mentalities in the Renaissance, ed. Brian Vickers (Cambridge: Cambridge University Press, 1984), 165-76.

80. Les préludes à l'harmonie universelle qui nous fournissent un témoignage clé sur la relation entre astrologie et musique. Ces questions curieuses utiles aux prédicateurs, au théologiens, aux astrologues, aux médecins, et aux philosophes (1634). See Wuidar, 58.

81. Gouk, Music, Science, and Natural Magic, 171-72: "Mersenne also recognized the influence of Ficino's Platonic academy on Baif and explicitly stated that Ficino's commentary on the Timaeus was 
Mersenne's censure of Fludd's ideas is based largely on the same reasoning that Kepler used in his critique; the search for universal harmonies begins for Kepler and Mersenne with an investigation and observation of nature, whereas for Fludd it is a priori. In short, these two views represent the empirical versus axiomatic methods of inquiry, respectively. Also akin to Kepler, Mersenne insists that the fundamentally mathematical nature of harmony cannot be divined from the imagination or the sort of flimsy analogies that both scientists saw in Fludd, but rather through the calculation of truths via precise observation. ${ }^{82}$ For instance, Mersenne's most famous contribution to mathematics is undoubtedly his discovery of the laws governing the vibration of strings and pendulumscalled Mersenne's Laws-a contribution that confirmed the applicability of mathematics to physics after Galileo, and paved the way for further discoveries, most importantly Isaac Newton's Philosophiae Naturalis Principia Mathematica (1687). ${ }^{83}$ As might be expected, these criticisms were not major problems for Fludd, whose Neoplatonism confirmed for him that the workings of the imagination had a basic and fundamental connection to the realities of the universe. By Newton's time, however, Fludd's Ficinian defences were becoming less credible. Unlike the intellectual climate at the beginning of the seventeenth century, by the end of the century studies of music and magic were not given much credence in England, and experimental philosophy continued to gain acceptance and recognition in scientific circles, in particular through the Royal Society.

\section{Musical machines and the Renaissance garden}

To conclude, I would like to mention briefly one of the stranger albeit most intriguing chapters in Fludd's De templo musicae: the seventh and final portion

the best exposition of Plato's musical thought available."

82. It should be noted that Fludd was by no means averse to experimentation since he conducted his own anatomical experiments. The physician William Harvey noted that he observed pathological experiments made by Fludd and others; see Geoffrey Keynes, The Life of William Harvey (Oxford: Clarendon Press, 1966), 100. Fludd himself writes about an experimental splenectomy that he performed on a dog; see Robert Fludd, Anatomiae amphitheatrum (Frankfurt: de Bry, 1625), 101.

83. H. Floris Cohen, Quantifying Music: The Science of Music at the First Stage of the Scientific Revolution, 1580-1650 (Dordrecht: D. Reidel, 1984), 97-112. 
of the treatise, "De Instrumento nostro Magno." ${ }^{44}$ As with many of his ideas and writings discussed above, Fludd confirms in this book his thoroughly Renaissance mentality, transported into and flavoured by seventeenth-century England. Fludd describes a newly invented musical instrument, "Our Great Instrument," a musical machine that does not require a musician and is meant to be hidden away in a garden or social place. In keeping with the English court's interest in automata, demonstrated by Drebbel's "Perpetuum mobile" for King James I of 1612, ${ }^{85}$ Fludd's musical inventions were well received. He writes, "Indeed, by the direction of my monochord, I have constructed a certain musical instrument equipped with brass chords [...] And it is not without approval and recommendation of eminent musicians (both French and English) acquainted with the English King's court." ${ }^{\text {86 }}$

Fludd describes a certain kind of mechanical psaltery, no doubt inspired by the musical inventions placed in numerous Renaissance gardens. ${ }^{87}$ Indeed,

84. As Hauge has noted, it was still relatively uncommon for music treatises published in the early seventeenth century to include information about instruments, and it is interesting to note that Fludd's book was published around the same time as Michael Praetorious's Syntagma musicum (Wittenberg and Wolfenbüttel, 1614-20).

85. Cornelius Drebbel (1572-1633), himself a Paracelsian physician, arrived in England in 1605 and was known to have created musical automata, pumps, and fountains. Drebbel was also involved in the staging of masques at James I's court along with the French engineer Salomon de Caus (1576-1626), whose Raisons de forces mouvantes (1615) provides descriptions of the construction of mechanical organs. The dramatist Ben Johnson (1572-1637), author of several masques, was a pupil of the Antiquarian William Camden, and was likely a patient of Fludd's; see Cyril E. Wright, "The Elizabethan Society of Antiquaries and the Formation of the Cottonian Library," in The English Library before 1700, ed. Francis Wormald (London: Athlone Press, 1958). On Drebbel see Robert Grundin, "Rudolph II of Prague and Cornelius Drebbel: Shakespearean Archetypes?” The Huntingdon Library Quarterly 54 (1991): 181-205, $190-91$.

86. Fludd, Clavis philosophiae et alchymiae Fluddanae (Frankfurt: Prostat apud Guilhelmum Fitzerum, 1633), 29; translation in Fludd, The Temple of Music, 15.

87. Kircher's Musurgia universalis also includes a description of a hydraulic organ built in the gardens of Quirinale in Rome. This image includes his depiction of Pythagoras at the blacksmith's; Aleotti also described mechanical organs which he himself built at Tivoli and Rome. A manuscript now housed at the University of California at Berkeley contains images of organs by Aleotti and also by Bartolomeo Scappi and Heinrich Zeising, all of which show similarities to the mechanism used by Fludd in his automaton organ: US-BEm, MS Berkeley Music Manuscript 1148 (dated ca. 1593), f. 35r; see Kimberley M. Parke, "Engineering Music: A Critical Inquiry into Giambattista Aleotti’s 'De la musica' (1593)" (PhD dissertation, University of California at Berkeley, 2006). 
in his "De motu elementari," Fludd refers to various automata that he observed on his European tour, including the gardens of the Palazzo del Quirinale in Rome and the Villa d'Este in Tivoli (see fig. 6.7 for an example of a musical machine that includes a keyboard). ${ }^{88}$ Using detailed engraved images as a guide, Fludd explains that his wonderful new instrument is constructed primarily of square and triangular frames bearing taught strings, tuned at various pitches. Wooden sticks (see figs. 6.5 and 6.6) are equipped with feather plectra that pluck the strings, in the manner of a harpsichord, by virtue of the fact that they are connected together in a mechanical device. Fludd's prime mover, consisting of ropes and counterweights, makes this string- and plectra-bearing structure descend slowly in a linear fashion, thus allowing the instrument to play without the aid of a human ${ }^{89}$ In what must have been a strange but delightful process, the instrument is pulled upwards again once it reaches the floor, playing the same music backwards.

The absence of a performer-a human presence that would have been necessary for Boethius's audible musica instrumentalis_-suggests that Fludd's instrument was meant to be a symbol of music, not as sounding art but rather the universal harmony of the heavens and of humanity. Such an instrument, hidden away in a garden or dining room, as Fludd suggests, would create an experience akin to Fludd's whole musical project: a union of Renaissance magic and early baroque musical style. Because of the mechanical limitations of the instrument, Fludd recommends that it be fitted to play, for example, a pavan, or combinations of pavans and galliards, and other pieces that are easily divisible into eight- and twelve-measure sections..$^{90}$ The context of the Renaissance garden in harmony with the harpsichord-like sound of music in the newer

88. Fludd visited l'Isola del Belvedere in Ferrara and also "observed a machine near Capua in the palace gardens of a certain Neopolitan count," Fludd, Utriusque cosmi [...] historia, vol. 1, "De motu," 458: "instrumentum [...] proper Capuam in palatii alicujus Comitis Neopolitani horto [...] obervavi."

89. Fludd writes that this mechanical device is based on machines built for "the roasting of foods", and as Hauge notes, the device is actually illustrated in cook books, for example in Bartolomeo Scappi's Cuoco secreto de Papa Pio Quinto (1596), and also in books about mechanical inventions, such as Heinrich Zeising's Theatri machinarum (1607-14); see Hauge, “Introduction," 12.

90. Since the music must be limited to forty measures, Fludd suggests pieces that can be divided into sections of eight or twelve measures. In his "De motu" are also found illustrations of other kinds of musical automata such as harps and organs which are operated by water, sand, or bells hooked up to clocks. One is reminded again of the famous water organ at the gardens of Villa d'Este in Tivoli. Fludd, Utriusque cosmi [...] historia, vol. 1, "De motu”, 433-501. See fig. 6.7 for an example. 
seventeenth century style stands as a testament to all of Fludd's musical ideas. The instrument, like Fludd's temple and monochord, revives the Neoplatonic ideas of the Renaissance, and joins them in an original arrangement to this preoccupation with "hidden truths," the hallmark of early seventeenth-century occult philosophy.

In the opening passage of "De Instrumento nostro magno," Fludd describes his invention:

This instrument, newly invented by us, will certainly, if it is examined by attentive eyes, not only bring profit to the listeners but also move their senses with the greatest charm [...] Therefore it will seem elegant and also quite pleasing and wonderful, to those dining or being present at a party, to hear unexpected music in a corner of the dining room without the presence of any moving living being, and through the greater part of the dinner or lunch to perceive a music piece composed of many symphonic parts and indeed sounding at the will of the master. ${ }^{91}$

Fludd's automata bring about the practical manipulation of nature. By inventing and building an instrument that plays on its own, hidden from sight, the author of this scene demonstrates his total dominion over nature in the act of creation: he not only creates the machine itself but pre-organizes in a single item all the potential acts of imitation, all the potential musical sounds that the instrument may produce. Man the scientist, musician, and philosopher has the power to imitate the act of creating natural things. He can do this by virtue of the fact that he is built by the same harmonic proportions and by the same magic as the universe: he is the microcosm. This confidence in the dignity of man, tuned to the heavens in the image of God, confirms Fludd's place among the last of the humanists.

Although Fludd's reconstruction of the Renaissance outlook was eventually abandoned by the scientific advancements of the later seventeenth century, his musical conception of the universe reflected courtly trends, and his reputation in the medical establishment was in the final evaluation quite strong; Fludd was one of the first supporters of William Harvey's theory of the 
circulation of blood. ${ }^{92}$ Fludd's musical books testify to the complex relationship between the scientific and courtly strata of contemporary society, and also reveal that it is not only musical practice but also broad scientific, medical, and philosophical conceptions of sound that comprise musical understanding in the early seventeenth century. Furthermore, these books confirm that the history of inaudible music is an integral part of the larger intellectual landscape of the late Renaissance. Such "hidden" histories, written and promoted by polymaths like Ficino and Fludd, may not lead us directly to the scientific revolutions of the Enlightenment, but they reveal much about the nature of scholarly debate in their own time- - the very mechanisms by which truths are made and unmade.

92. Walter Pagel, New Light on William Harvey (Basel: S. Karger, 1976), 9. Fludd writes that he had observed his colleague William Harvey's dissections of the heart, in Clavis Philisophiae et Alchemiae Fluddanae (Frankfurt: Prostat apud Guilhelmum Fitzerum, 1633), 33. See also Allen G. Debus, The Chemical Philosophy: Paracelsian Science and Medicine in the Sixteenth and Seventeenth Centuries (New York: Science History Publications, 1977), 286. 


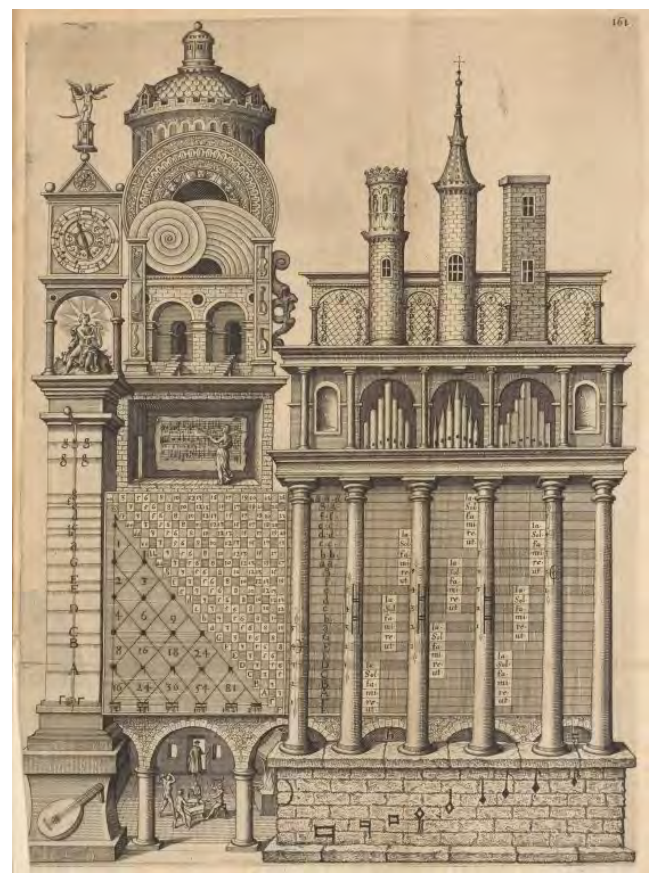

Figure 6.1. "The Temple of Music," Utriusque cosmi [...] historia, vol. 1, tract. 2, pp. 160-61 (Bayerische Staatsbibliothek).

\section{PRIMA DIMOSR ATIONB}

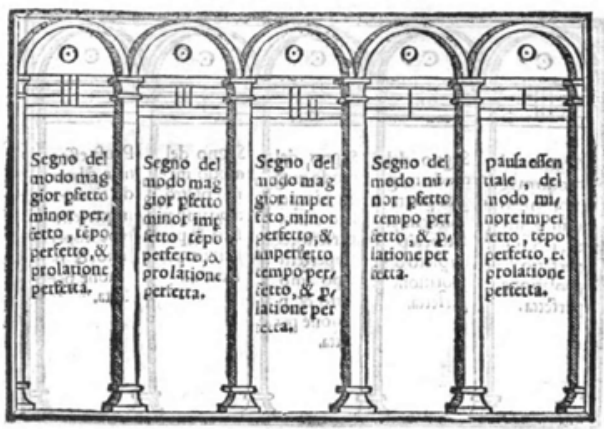

Figure 6.2. Pietro Aron, Toscanello in musica (Venice: Marchio Sessa, 1539), ch. 11, "Del valore di chiascheduna nota [...]" (Bayerische Staatsbibliothek). 


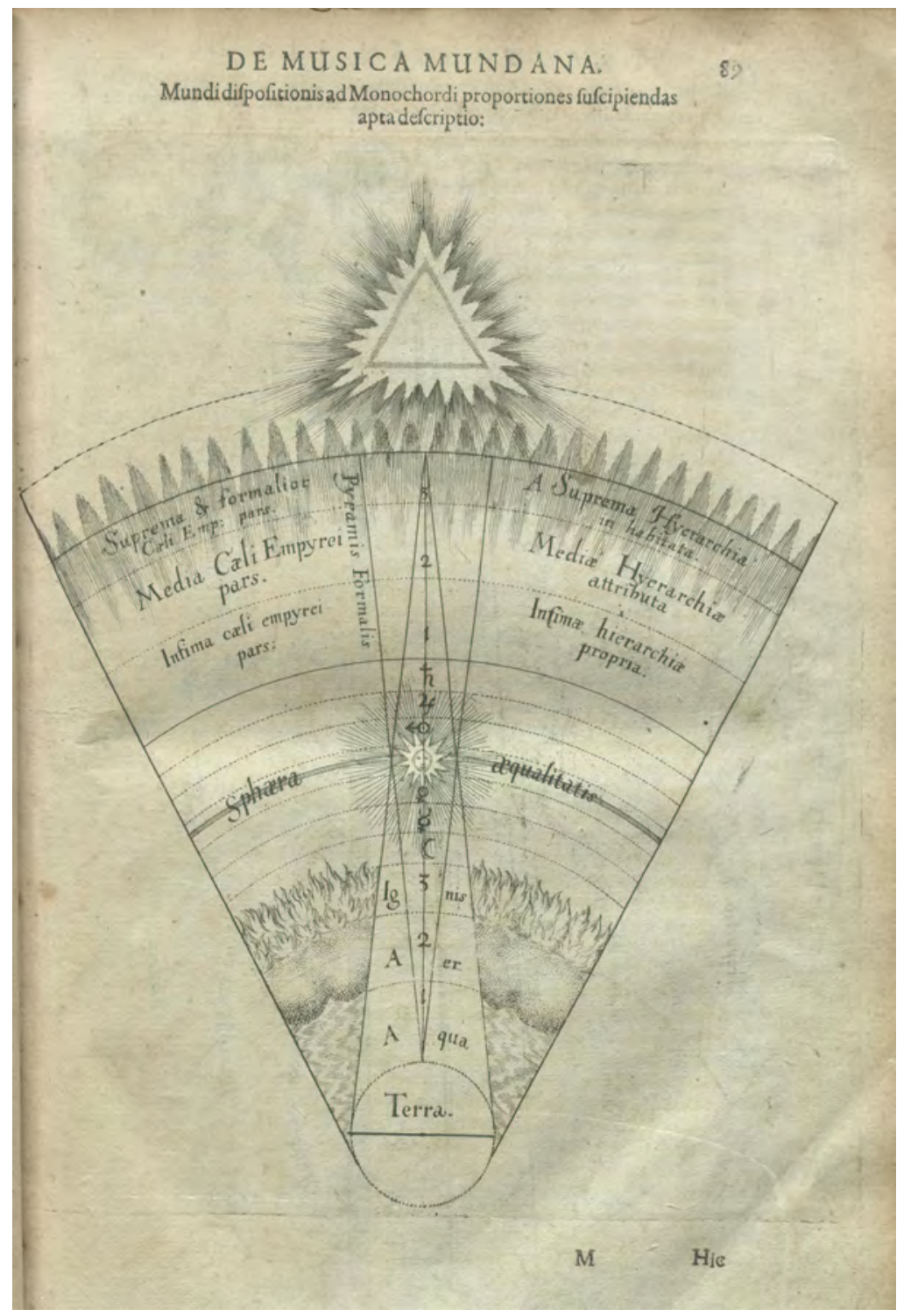

Figure 6.3. Fludd's interpenetrating pyramids, Utriusque cosmi [...] historia, vol. 1, tract. 1, p. 89 (Thomas Fisher Rare Book Library, University of Toronto). 


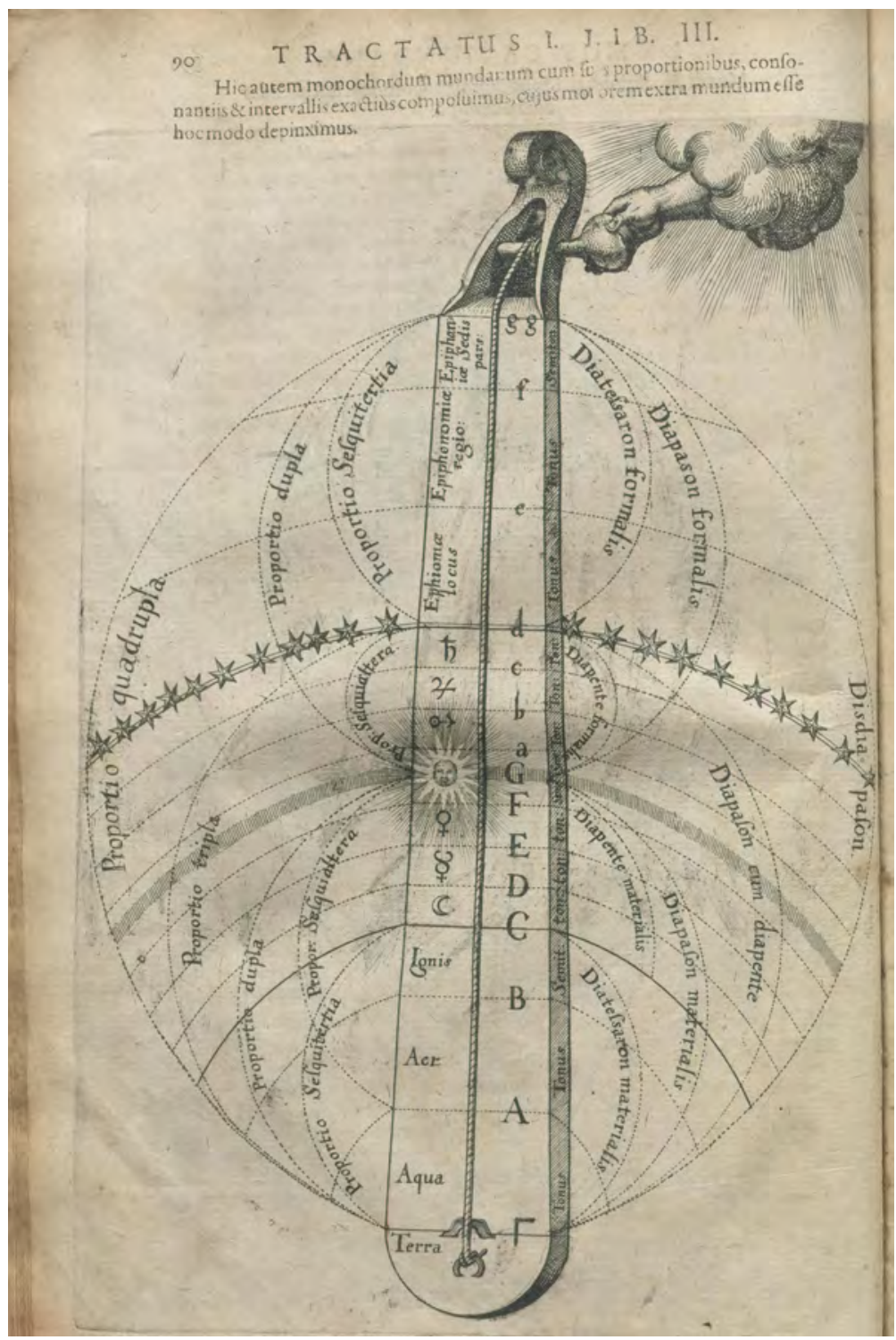

Figure 6.4. The monochordum mundi, Utriusque cosmi [...] historia, vol.1, tract. 1, p. 90 (Thomas Fisher Rare Book Library, University of Toronto). 


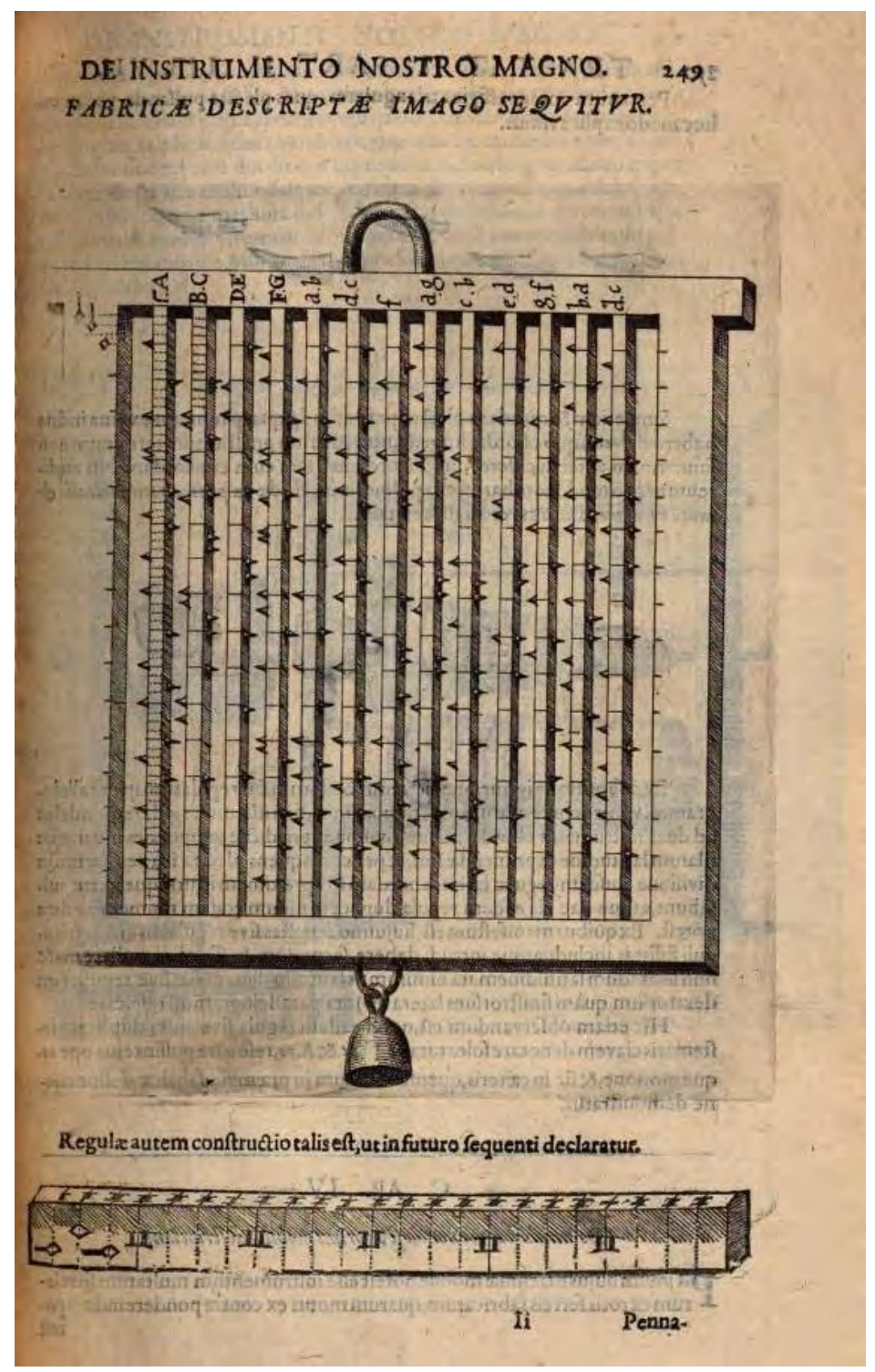

Figure 6.5. Utriusque cosmi [...] historia, "De instrumento nostro magno," vol. 1, tract. 2, p. 249. (Austrian National Library) 


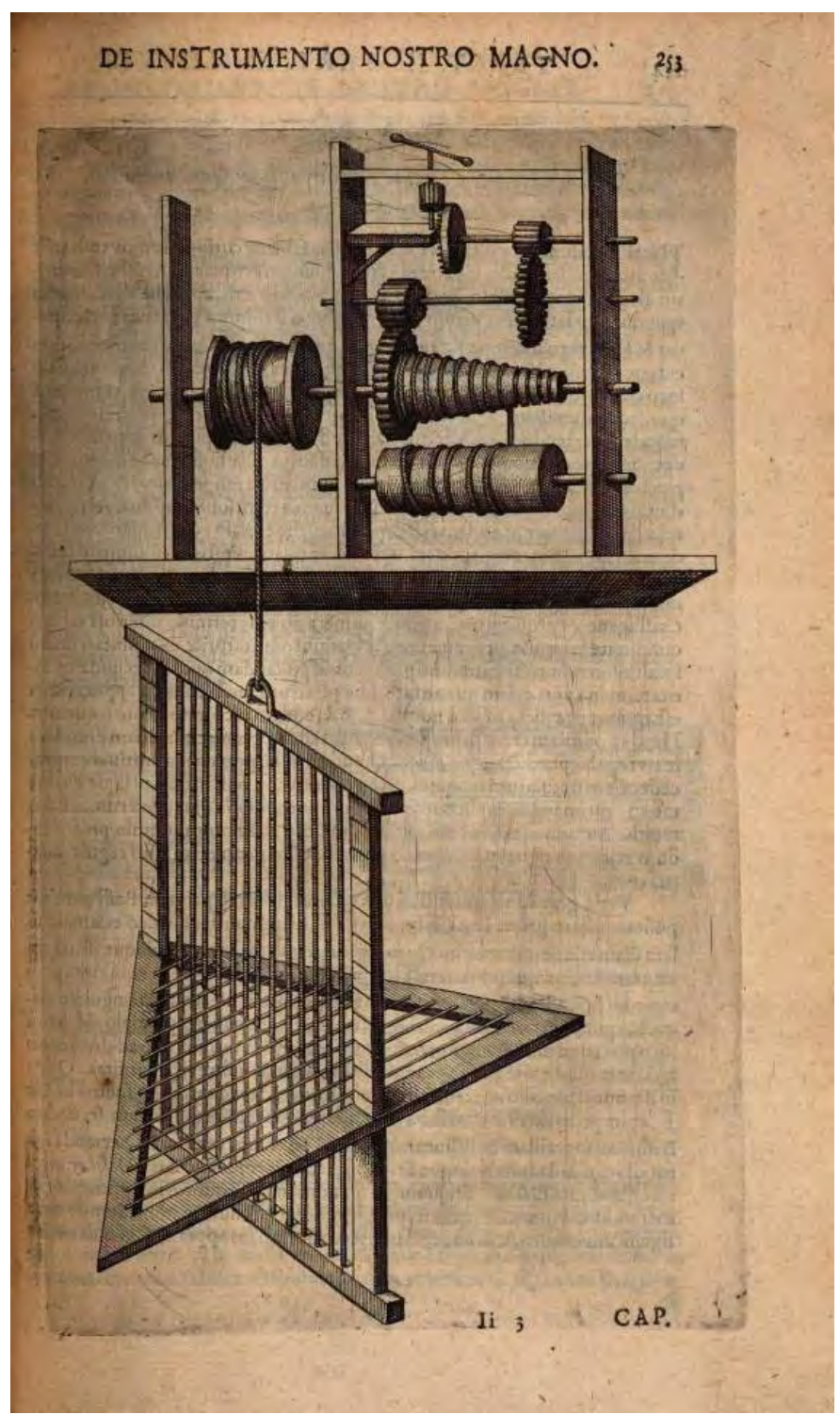

Figure 6.6. Utriusque cosmi [...] historia, "De instrumento nostro magno," vol. 1, tract. 2, p. 253. (Austrian National Library) 


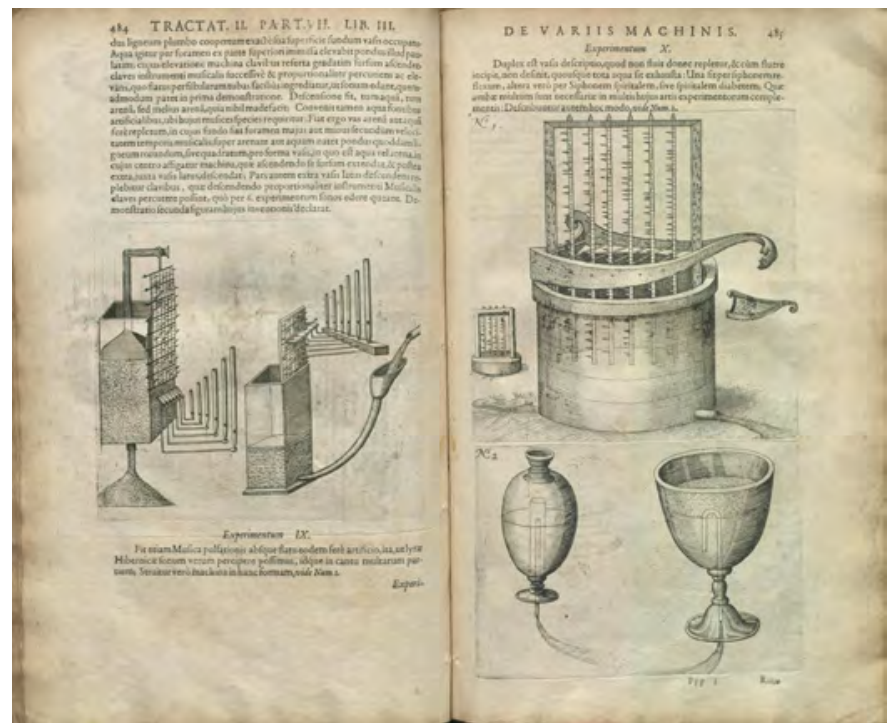

Figure 6.7. Utriusque cosmi [...] historia, vol 1, tract. 2, "De Motu Elementari," pp. 484 and 485. (Thomas Fisher Rare Book Library, University of Toronto) 